\title{
Accounting Restatements, Governance and Municipal Debt Financing
}

\author{
William R. Baber \\ Professor \\ McDonough School of Business \\ Georgetown University \\ Washington, D.C. 20057 \\ wrb7@georgetown.edu \\ Angela K. Gore \\ Associate Professor \\ School of Business \\ The George Washington University \\ Washington, D.C. 20052 \\ agore@gwu.edu \\ Kevin T. Rich \\ Assistant Professor \\ Sellinger School of Business and Management \\ Loyola University Maryland \\ Baltimore, MD 21210 \\ ktrich@loyola.edu \\ Jean X. Zhang \\ Doctoral candidate \\ School of Business \\ The George Washington University \\ Washington, D.C. 20052 \\ jxzhang@gwu.edu
}

August, 2011

The authors are grateful to Lisa Eiler, Dave Guenther, Lisa Kutcher, Steve Matsunaga, Terry O'Keefe, Jeremy Schwartz, and Ken Smith for helpful comments. Workshop participants at George Mason University, Loyola University Maryland, the University of Oregon, the 2010 Financial Accounting and Reporting Section (FARS) midyear meeting, the American Accounting Association national meeting, and the Governmental Accounting Standards Board/American Accounting Association Government and Nonprofit mid-year meeting offered useful suggestions. Kevin Rich gratefully acknowledges a summer research grant from the Accounting Circle at the University of Oregon's Lundquist College of Business. 


\title{
Accounting Restatements, Governance and Municipal Debt Financing
}

\begin{abstract}
This study investigates the consequences of financial restatements in the market for municipal debt. We find that mean municipal debt costs are 35 basis points higher following financial restatement disclosures, which suggests that financial reporting quality is an important input to municipal lending decisions. Specifications of debt costs that consider restatements and municipal governance characteristics interactively indicate that adverse consequences of restatements are mitigated by strong audit oversight and by provisions that encourage direct voter participation in the governance process. This evidence informs thinking about the role of auditor and voter oversight in the municipal financial reporting process.
\end{abstract}

Keywords: Accounting Restatements; Municipal Governance; Municipal Debt 


\section{Introduction}

This study investigates restatements of annual financial reports issued by U. S. municipalities. As in the corporate sector, such restatements are frequent and non-trivial in magnitude during the 2001-2004 period encompassed by the study. For example, the City of San Diego announced a $\$ 640$ million restatement - approximately $10 \%$ of total net assets - of fiscal year 2002 capital asset accounts. To appreciate the magnitude of the restatement, consider that the amount exceeds the $\$ 580$ million restatement in 2001 by Enron (Greenblatt 2005).

We focus on two aspects of municipal restatements. First, we investigate the consequences of restatements in the market for municipal debt. Second, we consider whether and how these consequences depend on two potentially important municipal governance characteristics: audit and voter oversight.

With respect to the first issue, evidence from the corporate sector suggests that restatements influence financing costs adversely (Abbott et al. 2004; Palmrose et al. 2004; Agrawal and Chadha 2005; Srinivasan 2005), although the severity depends in part on whether the restatement indicates a material irregularity (Hennes, Leone, and Miller 2008). The question of whether restatements are significant events in the context of municipal debt markets is an open issue, however. Potential lenders may construe restatements as evidence that local government managers mismanage or manipulate financial information to advance a political agenda. For example, Moody's cited concerns about financial management when twice downgrading San Diego’s bonds following its restatement disclosure (Moody's, 2004a, 2004b). On the other hand, the importance of financial reporting - and by extension, financial restatements - in the 
governmental setting is debatable (Zimmerman 1977). If municipal restatements reflect insignificant or unimportant reporting errors, rather than evidence of financial mismanagement or manipulation, then lenders may be indifferent to restatement disclosures. In the end, the consequence of restatements in municipal debt markets is a matter to be resolved empirically.

With respect to the second issue -- audit and voter oversight as a determinant of restatement consequences -- we are guided by a large body of research in the corporate setting which investigates associations between accounting restatements and corporate governance characteristics. Important differences between corporate and government enterprise discourage straightforward extrapolation of results from one context to another, and therefore, the extent that audit and voter oversight influences contracting between lenders and municipalities, also remains an open issue.

A distinguishing feature of the investigation is that we consider the importance of the municipal governance system as a whole, rather than individual municipal characteristics. An important innovation in this regard is that we construct indices designed to capture cross-sectional differences in the intensity and efficacy of audit and voter oversight in the municipal context. To validate our approach, we investigate the relative importance of municipal governance characteristics as determinants of municipal restatements. Multivariate specifications indicate that the collective explanatory power of audit and voter oversight measures for these data substantially exceeds that of size, financial condition, debt financing, regulatory oversight, and organizational form measures used frequently in studies of reporting quality. 
We then turn to the central objective of the study, which is to investigate the debt cost consequences of restatements and whether these consequences are affected by municipal governance characteristics. Our analysis indicates that municipal debt interest costs for new issues are substantially higher following restatement disclosures. Specifications of debt costs that consider restatements and governance characteristics interactively suggest that adverse consequences of restatements are, to an extent, mitigated by strong audit oversight and provisions that encourage direct voter participation in the governance process.

The specific contribution of the study is straightforward, as no prior study considers the adverse consequences of financial reporting quality in the municipal government context. Moreover, we consider municipal governance beyond what is in the literature currently.

The study also has more general implications for understanding financial reporting quality. In particular, aspects of the municipal sector differ from the corporate setting in ways that provide unique opportunities to examine the relation among governance attributes, restatements, and debt markets with new perspective and, in some cases, with greater statistical power. As examples, prior studies of the bond market consequences of restatements in the corporate sector are limited owing to a lack of data, and studies of the auditors' role with respect to restatements are restricted because the characteristics of audit firms lack sufficient variation in the corporate setting. In contrast, the availability of municipal bond data and the high degree of variation in the size and quality of municipal auditors facilitate statistical tests with greater power. The municipal sector also provides a richer context to investigate the role of outsider (voter-taxpayer) 
participation in the governance process. In particular, because transactions costs to voters of investing in municipalities are greater than to shareholders in capital markets, the incentive for direct participation in the governance process by outsiders is more conspicuous in the municipal context than in the corporate sector, where the exit option more effectively imposes discipline through market prices (Zimmerman 1977).

The remainder of the presentation is organized as follows. Features of municipal governance systems are described, and hypotheses regarding the consequences of financial restatements are developed, in Section 2. Section 3 describes the data and measures used in the study. Cross-sectional associations between restatements and audit and voter characteristics reported in Section 4 validate the oversight indices used in the primary investigation reported in Section 5. In particular, multivariate specifications described in section 5 consider the consequences of restatements in municipal debt markets and whether these consequences are influenced by audit and voter oversight characteristics. Concluding remarks are in Section 6.

\section{Municipal governance systems and hypotheses}

Consistent with the standard agency characterization (Jensen and Meckling 1976; Fama and Jensen 1983), we view municipal officials as agents who act on behalf of voters, lenders, or other participants in the municipal enterprise. This characterization is well-developed in the for-profit context, and thus, it is instructive to compare the incentives of voters/taxpayers who finance municipalities with the incentives of shareholders who finance commercial enterprise. In particular, transaction costs in political markets - that is, the costs of locating to a new municipality, including the direct cost of real estate transactions - are high relative to transaction costs in capital markets 
(Zimmerman 1977). For this reason, voters/taxpayers, who cannot easily dispose of investments in the municipal enterprise, are less able to price-protect themselves from opportunistic behavior by governmental agents. More specifically, voters/taxpayers who finance municipalities and consume municipal services find it costly to avoid taxes or discipline elected officials by disinvesting, i.e., by selling their real estate investments. These high transaction costs potentially elevate the importance of direct forms of oversight to protect voter/taxpayer investments relative to the use of exit to discipline municipal officials.

Given this distinguishing feature of governments, we characterize municipal governance as a portfolio of institutionalized procedures, practices, and mechanisms that provide monitoring and oversight and constrain actions in ways that align incentives of municipal officials with those of voters. To keep the analysis tractable, we restrict the investigation to two forms of municipal governance, which we designate audit oversight and voter oversight. These governance forms are developed below, but it is important to note that our treatment of governance mechanisms is neither exhaustive nor mutually exclusive. We are specifically interested in aspects of municipal governance that potentially influence the quality and reliability of municipal financial reporting. Thus, the objective is to achieve a framework that is sufficiently rich for considering interactions among governance alternatives as they relate to municipal financial reporting quality.

\subsection{Audit oversight and municipal reporting quality}

First, we consider audit oversight as a determinant of municipal financial reporting quality. If auditors discover and correct material errors during the normal 
course of the audit, then auditor participation can elevate financial reporting quality. On the other hand, such associations between auditor characteristics and measures of financial reporting quality potentially reflect systematic alignments of auditors with clients. For example, if high-quality auditors are more likely to attract high-quality clients with reliable accounting systems, then associations exist as a result of auditorclient alignments in the municipal audit market. Regardless of which characterization applies, we expect that financial reporting quality and auditor quality vary directly.

To investigate this expectation, we consider four auditor types. First, following arguments in DeAngelo (1981), we distinguish large nationally recognized (Big Four) audit firms. ${ }^{1}$ Second, Hammersley (2006) provides experimental evidence that suggests industry specialist auditors are more likely to detect complex accounting errors in industries such as the municipal sector where accounting practices are industry-specific. Thus, we identify non-Big Four auditors that specialize in municipal audits. Third, some state governments perform financial statement audits for municipalities, and therefore, we distinguish municipalities where the primary auditor is employed by the State. Auditors not in any of these three designations are assigned to the fourth (benchmark) class. It is important to note that this classification is not intended to order municipalities according to relative audit quality. As examples, we make no ex ante judgment about whether audit quality is greater for Big Four than for non-Big Four auditors, nor do we presume a difference in audit quality between public auditing firms and state government auditors.

\footnotetext{
${ }^{1}$ In the corporate context, DeFond and Jiambalvo (1991) using restatements, and Dechow, Sloan, and Sweeney (1996) using SEC enforcement actions, fail to find associations between financial reporting quality and the use of a Big Four auditor. To our knowledge, no prior study explores the role of audit committees in municipal financial reporting quality.
} 
In addition to the foregoing classification, we consider external auditor turnover. If replacement auditors reduce the potential risk of new clients by performing exhaustive audits, then financial reporting quality can be greater for initial, than for continuing, engagements. Evidence from the corporate sector supports this perspective. In particular, Lazer, Livnat and Tan (2004) find firms are more likely to restate prior financial information in the first year following an auditor switch.

Finally, we consider whether the municipality has an audit committee. The prevailing view from studies in the private sector context is that active audit committees improve financial reporting quality (McMullen 1996; Wild 1996), but relatively little empirical research considers how audit committees influence governmental financial reporting. ${ }^{2}$ Although audit committees in the municipal sector are voluntary, the Government Finance Officers Association (GFOA) in 1997 recommended that governmental units establish audit committees and, in 2002 and 2006, expanded and refined these recommendations to be more consistent with those in the corporate sector (GAO 2007).

\subsection{Voter oversight and municipal reporting quality}

We consider voter oversight in terms of the extent that voters participate in the municipal governance process. To develop a link between voter participation and municipal financial reporting, we presume that elected officials and their potential competitors require the support of individuals who provide the votes and other resources necessary to be elected (Laver 1981). The need to attract such support creates incentives

\footnotetext{
${ }^{2}$ Evidence in the corporate context is that firms with SEC enforcement actions or restatements are less likely to have audit committees (DeFond and Jiambalvo 1991; Dechow et al. 1996; Beasley 1996).
} 
to implement and promote policies - including financial reporting policies - that benefit supporting interests (Baber 1990).

Consistent with Baber and Sen (1984), we presume that the efficacy of voter oversight depends in part on political competition, defined in terms of the probability that incumbents are replaced. Although municipal elections take place at both the mayoral and council levels, following Evans and Patton (1987), we focus on council elections because many cities do not have separate mayoral elections. Moreover, in contrast with Baber (1983), we use a measure that does not rely on party affiliation, as local elections are often nonpartisan.

While regular elections are obvious mechanisms for exercising direct voter participation, some municipal charters and/or state laws provide mechanisms beyond scheduled elections for citizens to challenge incumbents. Some governments encourage direct voter participation in the municipal policy-making process. More specifically, direct initiative provisions permit citizens to place charter, ordinance, or home rule changes on the ballot through petition, and popular referenda allow citizens to petition to place charter, ordinance, or home rule changes advanced by the local government on the ballot before the change can take effect. While the presence of such provisions can provide incentives for elected officials to act in voters' interests, elected officials may not act to advance voter interests until confronted with credible voter action. We therefore include whether citizens recently attempt to recall (or remove) elected officials from office before the expiration of their terms as an indicator of voter activism. Gordon (2009) suggests such “direct democracy” provisions arise from principal-agent problems between voters and elected officials. Empirical evidence supports this characterization- 
for example, Matsusaka (2005) finds that direct democracy provisions are associated with lower municipal spending and taxes.

Bebchuk and Cohen (2005) posit that an important indicator of management entrenchment in the for-profit context is whether a firm has a staggered board of directors - that is, whether directors are elected in the same year or whether elections are staggered to ensure board control by incumbents. Prior research finds that staggered corporate boards discourage takeover (Bebchuk et al. 2002) and, as such, significantly insulate management from market discipline (Faleye 2007). In the municipal context, some municipalities have staggered councils where a subset of the council is elected (or reelected) in each election, while others have councils where all members are elected at the same time. Evidence and arguments described above and in Gore (2009) suggests that staggered councils are more entrenched than councils where all members are elected simultaneously.

These four provisions - initiative, referendum, recall, and staggered councils, each available in some, but not all, U.S. municipalities - facilitate direct voter participation in the municipal governance process.

\subsection{Determinants of municipal restatements}

To consider municipal financial reporting quality, we identify and distinguish municipalities that restate their financial statements. Financial accounting restatements are a well-researched topic in the corporate sector (Abbott et al. 2004; Palmrose et al. 2004; Agrawal and Chadha 2005; Srinivasan 2005; Baber et al. 2009). Following these studies, we characterize restatements as corrections of accounting misstatements made previously by negligent or, in the extreme, opportunistic managers. We presume further 
that substandard governance is at least partially responsible for financial reporting errors that manifest ultimately as accounting restatements. Given this context, investigating the extent that municipal governance characteristics correlate with accounting restatements informs thinking about the effectiveness of municipal governance as a determinant of financial reporting quality.

To this end, we specify the probability of restatement as

$$
\operatorname{Prob}(\text { restatement })=\mathrm{f}(\text { AUDIT; VOTER; controls }),
$$

where the dependent variable Prob(restatement) indicates the likelihood of a restatement between the years 2001 and 2004, AUDIT represents variables that consider the role of audit oversight, and VOTER indicates variables that consider the role of voter oversight. We use expression (1) to consider each category of oversight procedures both separately, and jointly.

\subsection{Consequences of restatements}

We consider the consequences of restatements in the context of municipal debt costs. More specifically, we estimate specifications of true interest cost (TIC), computed as the discount rate that equates the present value of debt service with proceeds of the issue, for municipal debt issues for a sample of municipalities that disclose financial reporting restatements between 2001 and 2004.

Prior literature finds corporate restatements are associated with negative stock price reactions (Palmrose et al. 2004), increases in the cost of equity capital (Hribar and Jenkins 2004), and higher debt costs (Graham et al. 2008). If municipal restatements are 
similarly interpreted by municipal bond investors, then we expect higher debt costs following restatement disclosure.

On the other hand, straightforward extrapolation of results from the private sector may not be justified. For example, if financial reporting is not important in political markets (Zimmerman 1977), or if municipal restatements do not indicate substantive material financial reporting or control irregularities (Hennes, Leone, and Miller 2008), then we anticipate no municipal debt cost implications. Moreover, even if the underlying irregularity is substantive, correcting the error can be positively, rather than negatively, interpreted.

Hypothesis 1: True interest costs (TIC) are independent of whether municipalities restate financial information.

If restatements have adverse consequences in municipal debt markets, then audit and voter oversight potentially possess important moderating effects on municipal debt costs. More specifically, restatements in the context of poor audit oversight can be viewed as evidence of serious control problems. Similarly, restatements in the context of restrictions that discourage direct voter involvement can be interpreted as evidence of entrenchment. If so, then we expect that the consequences of municipal restatements are attenuated when measures indicate strong audit or voter oversight.

Hypothesis 2: The consequences of municipal restatements are independent of audit and voter oversight.

Hypotheses 1 and 2 are considered using specifications of the following general form. 


$$
\begin{aligned}
\text { TIC }=\mathrm{f} & (\text { POST-RESTATEMENT; GOVERNANCE; } \\
& \text { POST-RESTATEMENT * GOVERNANCE; controls }),
\end{aligned}
$$

where POST-RESTATEMENT is a dummy variable that distinguishes municipal debt issues after $($ POST-RESTATEMENT $=1)$ from issues before $(P O S T$-RESTATEMENT $=0)$ the restatement disclosure, and GOVERNANCE is a set of municipal characteristics that consider audit and voter oversight. Control variables indicate determinants of TIC documented in prior literature (e. g., Baber and Gore 2008).

Negative estimates on the main effect POST-RESTATEMENT suggest adverse consequences to restatement disclosures. Estimates on the interactions POSTRESTATEMENT * GOVERNANCE indicate the extent that municipal governance characteristics mitigate or exacerbate the consequences of financial restatements on municipal debt costs.

\section{Sample and data}

\subsection{Sample selection}

[Table 1 goes here]

Sample selection procedures are summarized in Table 1 (Panel A). We begin with 4,244 municipalities (cities and towns) that respond to a 2001 governance survey conducted by the International City/County Management Association (ICMA). To facilitate comparability with prior studies (e.g., Copley et al. 1995), and to ensure data availability, we identify 365 of these municipalities with population greater than 50,000 . For $253(69.3 \%)$ municipalities, we obtain through either an online search or a mail 
request, 741 financial statements for fiscal years 2001 to 2004, a period when financial restatements for publicly-traded companies are particularly high-profile.

Following Palmrose et al. (2004), restatements are identified when municipalities refer to restatements or prior period adjustments within the financial reports through either footnote disclosure or reference within the financial statements. We exclude restatements that result from implementations of GASB standards and retrospective reclassifications between funds.

Details of voter oversight provisions, municipal council characteristics, and political competition measures are from the 2001 ICMA survey. ${ }^{3}$ Audit committee details are obtained through a mail survey and follow-up procedures. Auditor and auditor turnover data are from either the financial reports or the Single Audit Database provided by the Federal Audit Clearinghouse. Control variables are computed using data from the Census Bureau's Annual Survey of Governments, with the exception of state reporting oversight classifications, which are from Baber and Gore (2008). Of the 253 municipalities with financial reports available, we obtain details about governance characteristics and control variables for 207 municipalities, which are used in multivariate specifications of restatement probabilities.

To consider the consequences of restatements, we compare municipal debt issued before and after restatement disclosures. Following prior literature (e.g., Baber and Gore 2008; Graham et al. 2008), we use relatively long windows, as debt issues are infrequent for most municipal governments. More specifically, we use Thomson Financial's SDC Platinum data to identify debt issues 36 months before and 36 months after the

\footnotetext{
${ }^{3}$ The ICMA governance survey is conducted every five years. We use the survey available at the beginning of our sample time frame.
} 
restatement disclosure for 57 municipalities that both have restatements and that issue debt. Because municipal restatements are likely to be disclosed initially in the annual financial report, we identify the date of the auditors' report as the event date. For municipalities with multiple restatements, we retain only the first restatement to avoid overlapping event windows (Graham et al. 2008). ${ }^{4}$ This procedure yields 373 unique debt issues during the 2001 to 2004 period.

\subsection{Independent variables}

\subsubsection{Audit oversight measures}

Auditors are classified as whether the municipality engages a Big Four auditor (Big 4 auditor), a municipal specialist as defined by membership in the Governmental Audit Quality Center ${ }^{5}$ (and that is not a member of the Big Four), or a state auditor - that is, when the state government auditor's staff conducts the municipal audit. All three of these indicator variables are set to zero for municipalities that engage non-Big Four auditors that are not specialists or government auditors. Auditor switch is an indicator variable equal to one if the municipality has a new auditor during the sample time frame. Audit committee is an indicator variable set to one for municipalities with audit committees.

If audit characteristics are substitutes in the oversight process, then focusing on individual audit characteristics can weaken or obscure associations when audit oversight is considered as a system. Thus, we also construct a combined audit oversight measure,

\footnotetext{
${ }^{4}$ Results are comparable when we restrict the investigation to issues 24 months before/after the restatement, specify the fiscal year end (rather than the auditor's report date) as the event date, omit municipalities with multiple restatements, or omit municipalities in the two states with the highest number of bond issuances.

${ }^{5}$ The AICPA's Government Audit Quality Center identifies audit firms that satisfy membership requirements, and at www.gaqc.aicpa.org/memberships. Results (not tabulated) are comparable those reported for an alternate municipal audit specialist variable that defines a specialist as a firm with municipal clients greater than the state median.
} 
designated Audit oversight index, as (Big 4 auditor + Municipal specialist + Audit

committee $+(1-$ Auditor switch $))$. Big 4 auditor and Municipal specialist are mutually exclusive categorizations, and therefore, Audit oversight index varies between 0 and 3 , where higher values indicate greater audit oversight of the financial reporting process. ${ }^{6}$

\subsubsection{Voter oversight measures}

Five measures consider voter oversight. Staggered is an indicator variable equal to one for municipalities with staggered council election cycles. Political competition, considered in terms of the probability that incumbents are defeated, is an indicator set to one when incumbents running for election are not re-elected to the city council during the 2001-2004 period. To consider initiative and referenda, we set the indicator variable no provisions equal to one if the municipality has neither initiative nor referendum provisions, and both provisions equal to one if the municipality has both of the provisions. Municipalities with either, but not both, provisions have both indicator variables set to zero. Recall is an indicator variable set to one in municipalities where citizens attempt to recall either the mayor or a council member in the preceding five years.

We also construct a combined measure of voter oversight computed as the Voter oversight index $=($ Political competition $+(1$ - Staggered $)+$ Both provisions + Recall attempt). The Voter oversight index varies between 0 and 4, with higher values indicating greater financial reporting oversight.

\footnotetext{
${ }^{6}$ Signs for indicator variables used to construct the audit and voter oversight indices are verified by specifications of restatement probabilities reported later in Table 3. In particular, negative (positive) parameter estimates in Table 3 indicate lower restatement probability and therefore greater (lower) financial reporting quality. Thus, variables with negative (positive) estimates in Table 3 are $+1(-1)$ when computing the audit and voter oversight indices. Factor analysis is not employed because the governance measures are indicator variables, and some are categorical by construction (e.g. auditor type). Factor analysis is primarily designed for continuous variables; the use of categorical variables introduces negative spurious correlation which renders factors inferior to indices used in this study (Kolenikov and Angeles 2004).
} 


\subsubsection{Control variables}

We control for state municipal accounting requirements, the city manager form of government, municipal size, debt outstanding, and financial distress. Following Baber and Gore (2008), we set an indicator variable (GAAP) equal to one for municipalities in states that require GAAP accounting for all municipalities; a separate indicator variable (Unregulated) distinguishes states with no municipal reporting requirements; and both variables are set to zero for municipalities in states with hybrid or state-specific municipal accounting requirements. Council-manager is an indicator variable equal to one if the municipality has a council-manager form of government where the city manager is the chief executive, and zero otherwise. Prior literature (e.g., Copley 1991) suggests the council-manager form of government is positively associated with financial reporting quality. Municipal size is the log of population, and debt outstanding is the total debt per capita, both computed using 2001 to 2004 means for each municipality. ${ }^{7}$ Financial distress (Deficit) is an indicator variable equal to one for municipalities with operating expenditures greater than total revenues.

\section{Analysis of restatement probabilities}

\section{[Table 2 goes here]}

To consider associations between restatements and municipal governance characteristics, we use one observation per municipality, as most municipal governance characteristics are invariant across time. Table 2 summarizes characteristics for the full sample, and for sub-samples partitioned according to whether the municipality discloses a

\footnotetext{
7 To reduce the potential impact of outliers, size and debt measures in the $1 \%(99 \%)$ tails of the
} distributors are set to $1 \%(99 \%)$ values. 
restatement between 2001 and 2004. Chi-square statistics for comparisons of means for 110 municipalities with and 97 municipalities without restatements are in the right-most column.

Univariate comparisons indicate that municipalities with restatements are less likely to engage a Big Four auditor, but more likely to be audited by the state; and are more likely to experience an auditor switch. Moreover, audit oversight as measured by the Audit oversight index is lower for municipalities with restatements. Differences are not statistically significant ( $\alpha<0.05$, two-tailed) for voter oversight measures, however, considered either individually or jointly using the Voter oversight index. Finally, restatements are less likely for municipalities in states that require GAAP accounting.

\section{[Table 3 goes here]}

Results for the multivariate specification of restatement probabilities indicated by expression (1) are summarized in Table 3. The first three columns show estimates for a logit specification where individual governance characteristics are considered; columns 4 through 6 show estimates for the combined measures Audit oversight index and Voter oversight index. We are concerned about correlations between audit and voter oversight characteristics, and therefore, we provide separate specifications in columns 2 and 3 and in columns 5 and 6 where each governance dimension is considered separately along with control variables. To assess the incremental effect of oversight variables, we also show in column 7 a benchmark specification where control variables are included without oversight measures. 


\subsection{Audit oversight measures}

Consider the results for audit oversight variables. Notice in Table 3 that the first three audit oversight measures are indicator variables that distinguish municipalities with Big Four auditors, non-Big Four municipal specialists, and state auditors, respectively. Thus, estimates indicate mean effects of the specified auditor type relative to the benchmark case where the municipality engages a non-Big Four, non-state government auditor that is not a municipal audit specialist (member of the Governmental Audit Quality Center).

As a whole, the auditor classification indicates at least two important points. First, restatement is more likely when state auditors are employed than when independent public accountants are employed. The implication of the result is not straightforward, however. One possibility is that state auditors focus more on operational efficiency - for example, on the disposition of funds provide by the state - than on the veracity of financial information, and therefore, oversight provided by state auditors is substandard on the financial reporting dimension. Another, not necessarily mutually exclusive possibility is that, as part of a related political system, state auditors are less independent, and therefore, provide lower quality financial oversight than independent auditors. We are reluctant to speculate further, as additional investigation is required to justify convincing conclusions. Even so, if the objective is to increase financial reporting quality by discouraging restatements, then these results support the use of independent public accountants.

The second point worth noting is that restatements are less likely when the municipality engages a Big Four auditor or an auditor that specializes in municipal audits. 
Either because of audit firm size (DeAngelo 1981) or because of the firm's position as a specialist, Big Four and municipal specialist auditors have incentives to be concerned about their reputation. Thus, the evidence suggests that auditor reputation is an important dimension of audit oversight, and by extension, of municipal financial reporting quality.

The positive association with auditor switches indicates that restatements are more likely when the municipality changes its audit firm. This result raises concerns about causality, as it is unclear whether the restatement causes the municipality to change auditors or whether a new auditor identifies prior accounting practices that require restatement. To investigate further, we examine sixty municipalities with available information that experience one auditor switch during the sample period (seven municipalities change auditors twice). These sixty municipalities experience 51 restatements. Seven restatements (13.7\% of the 51$)$ occur in the year prior to the auditor switch; twenty-nine (65.9\%) occur in the first year of the new auditor, ten (19.6\%) occur in the second year following the auditor switch; and five (9.8\%) occur three or four years after the auditor switch. This timing of restatements relative to auditor changes suggests that new auditors - for whatever reason - question accounting practices sanctioned by prior auditors, which in at least some cases manifest ultimately as accounting restatements. These results are also consistent with those of the corporate sector in Lazer, Livnat and Tan (2004), which indicate that firms are more likely to restate prior financial information in the first year following an auditor switch. If we presume auditor rotation to be a component of audit oversight - that is, something that provides independent assessment of financial reporting - then this evidence informs thinking about policies that require occasional auditor rotation in the municipal context. 
Notice that municipalities with audit committee are neither more nor less likely to restate. To investigate further, we consider measures of audit committee financial expertise and independence. These specifications (results not tabulated) indicate no statistically significant association between restatements and audit committee composition characteristics. ${ }^{8}$ Thus, the analysis does not support the notion that audit committees - at least as audit committees are presently constituted - reduce the probability of financial restatement.

Finally, results in columns 4 and 5 of Table 3 indicate the consequence of considering audit characteristics in the aggregate. In particular, greater audit oversight corresponds with lower restatement probability ( $\alpha<0.01$, two-tailed).

\subsection{Voter oversight measures}

Four points emerge from studying associations between the voter oversight characteristics and restatements. First, municipalities with staggered councils are more likely to experience restatements. Recall that staggered councils are a proxy for municipal manager entrenchment, to the extent that the provision discourages major change in - i.e., complete and immediate turnover of - the incumbent municipal council. Second, restatements are less likely in municipalities with both initiative and referendum provisions, features that promote direct voter participation. Third, municipalities that recently experience a recall attempt, which we interpret as an indication of the incentives and ability of voters to intervene in municipal government, are also less likely to experience a financial restatement. Finally, associations between the probability of

\footnotetext{
${ }^{8}$ One explanation for finding no significant relation for either the presence or composition of audit committees is that audit committee formation is voluntary and therefore endogenous to the system. To consider this possibility, we estimate a specification of whether the municipality has an audit committee and include the inverse Mills ratio in specifications with audit committee characteristics (Heckman 1979). Results (not tabulated) for this procedure are similar to those described above.
} 
financial restatement and the Voter oversight index are negative and statistically significant ( $\alpha<0.01$, two-tailed), both when considered separately (column 6 of Table 3 ) and when considered with audit oversight (column 4 of Table 3). As a whole, the results suggest that entrenched municipal officials - that is, managers in cities where voter intervention is a less credible threat - are more likely to experience restatements.

\subsection{Associations for control variables}

Results in Tables 2 and 3 consistently indicate that restatements are less likely in states that require GAAP accounting for all municipalities. In apparent contradiction, however, results in column 3 of Table 3 , where state oversight measures are considered without audit oversight measures, indicate that restatements are also less likely for municipalities in states that impose no accounting requirements at all. When interpreting the evidence, one needs to consider that municipalities in the benchmark group can and do choose GAAP accounting voluntarily. Moreover, state accounting requirements can proxy for other forms of state oversight that potentially influence municipal financial reporting practices and procedures (Baber and Gore 2008). Thus, we cannot confidently offer conclusions about the role of GAAP or the importance of state oversight in municipal financial reporting quality.

Finally, we find evidence that restatements are less likely for municipalities organized according to the council-manager model. Such evidence supports the results reported elsewhere that financial reporting quality is greater when the council-manager form is in place (Evans and Patton 1983; 1987; Copley 1991). 


\section{Consequences of Restatements in Municipal Debt Markets}

\subsection{Restatements and debt costs}

[Table 4 goes here]

Table 4 provides characteristics for 373 debt issues by municipalities that restate financial statements, issue municipal debt surrounding the restatement disclosure, and have the data required to estimate complete multivariate specifications. The focus of the investigation is the true interest cost (TIC), computed as the discount rate that equates the present value of debt service with proceeds of the issue. Other characteristics are identified in prior studies (e.g. Baber and Gore 2008) as determinants of TIC.

[Table 5 goes here]

We begin by estimating an OLS specification of TIC minus the prevailing market index. The specification includes an indicator variable set equal to one (zero, otherwise) to distinguish issues following, from issues preceding, restatements. The estimate on the post-restatement indicator variable, displayed in the first column of Table 5, indicates a statistically significant $(\alpha<0.01$, two-tailed) 35 basis point increase in municipal debt costs after the restatement. ${ }^{9}$ The specification in the second column includes variables identified in Baber and Gore (2008) to consider factors other than restatements that potentially influence TIC. The Bond Buyer Index is included as an independent variable, and thus, the dependent variable is raw TIC. The estimate on the post-restatement indicator variable indicates mean municipal debt costs are greater by 35 basis points

\footnotetext{
${ }^{9}$ This specification, as do all specifications displayed in the table, includes indicator variables to consider mean state effects (estimates not reported).
} 
following a restatement $(\alpha<0.01$, two-tailed). Thus, both specifications indicate nontrivial adverse consequences to restatements in municipal debt markets. Specifically, hypothesis 1 - that debt financing costs are independent of the restatement event - is rejected in favor of the alternative that municipal debt costs are significantly higher following a restatement.

\subsection{Analysis using composite audit and voter oversight measures}

Given the finding that restatements increase municipal debt costs, the research question addressed by hypothesis 2 is whether municipal governance characteristics mitigate the adverse consequences of restatements. Thus, in columns 3 through 5, we focus on interactions between the combined governance measures and the dummy variable that distinguishes post-restatement observations (Audit oversight X postrestatement and Voter oversight $X$ post-restatement). The third and fourth columns display specifications that include either of these interactions (along with the corresponding main effects) and the fifth column displays results where both governance dimensions are included.

The results indicate the benefits of audit oversight in municipal debt markets. More to the point, the estimate -0.27 reported in column 5 for the Audit oversight $X$ postrestatement interaction indicates that increases in debt costs that follow from restatements are significantly lower for municipalities with high audit oversight indices. Moreover, the result is robust in column 3 where the voter oversight measure is not included in the specification. Evidence regarding the role of voter oversight is similarly persuasive. In particular, the estimate -0.20 in column 5 on Voter oversight $X$ post-restatement suggests that consequences of accounting restatements are less severe when voter oversight is high. 
Main effects of the audit and voter oversight measures are worth noting. Positive estimates on the main effect Audit oversight potentially indicate that municipalities with high debt costs have incentives to invest in audit oversight to reassure lenders. Positive estimates on Voter oversight in column 5 potentially reflect greater borrowing by municipalities in response to voter demands for services financed by debt rather than by taxes. These effects are not the focus of the investigation, and therefore, we do not go beyond these speculations.

\subsection{Analysis using individual audit and voter oversight characteristics}

[Table 6 goes here]

Table 6 summarizes evidence for individual governance characteristics. The first row of the table shows the estimate for the main effect of the indicated governance characteristic and the second row shows the estimate for the interaction between the governance characteristic and the Post-statement dummy variable. Estimates on control variables, which are included in this specification, are not reported.

Notice first that the positive and statistically significant estimate 0.71 on the Postrestatement dummy variable is in line with the 0.93 estimate in column 5 of Table 5 where governance characteristics are considered using the composite indices. This result confirms nontrivial adverse consequences in municipal debt markets from financial restatements.

Expected signs for the interactions between the governance characteristic and the post-restatement dummy variable are displayed in the first row of the table. These expectations are informed by cross-sectional associations displayed in Table 3. In 
particular, with respect to audit oversight variables, we anticipate that engaging a Big Four auditor, a municipal specialist, or maintaining an audit committee mitigates the adverse consequences of accounting restatements. We are uncertain about the implications of using a state auditor or changing the external auditor, however, and therefore offer no predictions about the sign for these associations.

Regarding the voter oversight variables, we presume that staggered election of council members and having neither initiative nor referendum provisions discourages direct voter participation and thus weakens voter oversight. Hence, we expect positive interactions for these characteristics. In contrast, we expect that political competition (council turnover), having both initiative and recall provisions, or experiencing a recall attempt is evidence of strong voter oversight, and therefore, we anticipate negative interactions for these characteristics.

The evidence in Table 6 generally supports the notion that strong audit or voter oversight attenuates the consequences of financial reporting restatements, although support for this expectation is not uniform for all individual characteristics. Regarding the audit oversight variables, we find that municipalities with auditor switches during the 2001 to 2004 period experience more substantial adverse reactions to restatements than municipalities that do not switch auditors. This result raises the possibility that auditor terminations by municipalities that experience restatements are perceived negatively by lenders. These perceptions potentially reflect the circumstances that precipitate auditor terminations or concerns that new auditors are less well informed, and thus provide lower quality municipal audits than do continuing auditors. Unfortunately, the data do not permit a convincing investigation of which explanation applies. 
In contrast with the evidence in Table 3, which does not support the notion that audit committees discourage accounting errors that ultimately manifest as restatements, evidence in Table 6 suggests that municipal audit committees mitigate the adverse consequences of restatements when they occur. In particular, the statistically significant negative estimate on the interaction (Audit committee $X$ post-restatement) indicates that increases in debt costs following restatement disclosures are lower by 39 basis points than increases following restatement disclosures by municipalities that do not have audit committees.

Also in contrast with evidence in Table 3, which indicates that restatements are less likely for municipalities that engage Big Four auditors or auditors that specialize in municipal engagements, results in Table 6 indicate that the debt market consequences of restatements are independent of external auditor type. That is, estimates on interactions between the post-restatement dummy variable and whether the municipality engages a Big Four auditor, a municipal specialist, or a state auditor are not statistically significant at conventional reliability levels $(\alpha<0.10$, two-tailed).

Evidence in Table 6 also indicates the relevance of individual voter oversight measures as determinants of the consequences of restatements in municipal debt markets. The -0.39 estimate on the interaction between the post-restatement dummy variable and the measure of political competition; the 0.31 estimate on the interaction with the dummy variable that distinguishes municipalities with neither initiative nor referendum provisions; and the -0.33 estimate on the interaction with recent recall attempts are each statistically significant and consistent with expectations. Associations are not statistically significant, however, for interactions between the post-restatement dummy variable and 
whether the municipality has a staggered council or whether the municipality has both initiative and referendum provisions. As a whole, the evidence in Table 6 supports the associations in Table 5 for the composite audit and voter oversight indices. Thus, the null hypothesis 2 is rejected in favor of the alternative that the adverse debt consequences of restatements are mitigated by audit and voter oversight.

\subsection{Sensitivity}

We use subsamples of the data to consider issues that can bias associations for the primary sample. First, if restatements influence municipal debt costs, then decisions to issue debt are potentially affected. If so, then the sample of municipal debt issues before restatements can differ systematically from the sample of issues after restatements on dimensions not considered by control variables. To address this concern, we estimate specifications for a sample of 342 debt issues for municipalities that issue debt both before and after the restatement. Second, from the analysis of restatement determinants, we suspect that the incidence of, and circumstances that cause, restatements by municipalities that switch auditors may differ from those for municipalities that do not switch auditors. Moreover, auditor switches themselves may influence, or may be influenced by, decisions to seek debt financing. Thus, we estimate the specification for a sub-sample of 261 debt issues for municipalities that engage the same auditor throughout the period encompassed by the study. Results for these sub-samples are similar to those reported in Tables 5 and 6, although, owing to smaller sample size, some associations are less significant statistically. 


\section{Concluding remarks}

We investigate the consequences of financial restatements in municipal debt markets, and the role of audit and voter oversight in mitigating or exacerbating these effects. Interest in these issues is motivated by recent concerns about financial reporting quality at both the federal and local government levels, which suggest that governmental restatements undermine public trust and confidence (GAO 2010; Walker 2005). To our knowledge, the study is the first to consider adverse consequences of financial reporting quality in the municipal government context. Moreover, we provide a more comprehensive treatment of municipal governance than extant literature, in part by constructing indices designed to capture cross-sectional differences in municipal audit and voter characteristics.

The results indicate that municipal debt interest costs are substantially higher following restatement disclosure, which suggests that financial reporting quality is important in municipal bond markets. Moreover, the study has potentially important policy implications regarding audit and voter oversight in the municipal context. We find that restatements are less likely, and that the adverse consequences of restatements in municipal debt markets are less substantial, when audit oversight is strong. These results suggest the importance of the municipal audit function as a component of the municipal oversight process. Policy implications of the investigation of voter oversight are similarly straightforward. The results indicate that restatements are more likely, and the increase in debt financing costs following restatements are more substantial, when municipal managers are entrenched - that is, when the ability of voters to alter the composition of the city council or to intervene directly in the municipal decision-making 
process is restricted. This result squares with evidence reported for the corporate sector where the likelihood of accounting restatement is greater when the costs to shareholders of direct involvement in corporate decision-making are relatively high (Baber et al. 2009). As a whole, results reported in the study inform thinking about the implications of proposed changes in municipal governance and oversight procedures, such as those involving municipal audit committees (e.g., GFOA 2006). 


\section{References}

Abbott, L., Parker, S., Peters, G., 2004. Audit committee characteristics and restatements. Auditing, A Journal of Practice and Theory 23 (1): 69-87.

Agrawal, A., Chadha, S., 2005. Corporate governance and accounting scandals. Journal of Law and Economics 48 (2): 371-406.

Baber, W., 1983. Toward understanding the role of auditing in the public sector, Journal of Accounting and Economics 5 (3): 213-227.

Baber, W., 1990. Toward a framework for evaluating the role of accounting and auditing in political markets: The influence of political competition. Journal of Accounting and Public Policy 9 (1): 57-73.

Baber, W., Gore, A., 2008. Consequences of GAAP disclosure regulation: Evidence from municipal debt issues. The Accounting Review 83 (3): 565-591.

Baber, W., Kang, S., Liang, L., Zhu, Z., 2009. Strong boards, management entrenchment, and accounting restatement. Unpublished working paper, The George Washington University.

Baber W., Sen, P., 1984. The role of generally accepted reporting methods in the public sector: An empirical test. Journal of Accounting and Public Policy 3 (2): 91-106.

Beasley, M. S., 1996. An empirical analysis of the relation between the board of director composition and financial statement fraud. The Accounting Review 71 (4): 443-465.

Bebchuk, L., Coates IV, J., Subramanian, G., 2002. The powerful antitakeover force of staggered boards: theory, evidence, and policy. Stanford Law Review 54: 887-951.

Bebchuk, L., Cohen, A., 2005. The costs of entrenched boards. Journal of Financial Economics 78 (2): 409-433.

Copley, P., 1991. The association between municipal disclosure practices and audit quality. Journal of Accounting and Public Policy 10 (4): 245-266.

Copley, P., Gaver, J., Gaver, K., 1995. Simultaneous estimation of the supply and demand of differentiated audits: Evidence from the municipal audit market. Journal of Accounting Research 33 (1): 137-155.

Dechow P., Sloan, R., Sweeney, A., 1996. Causes and consequences of earnings manipulation: An analysis of firms subject to enforcement actions by the SEC. Contemporary Accounting Research 13 (2): 1-36.

DeFond, M., Jiambalvo, J., 1991. Incidence and circumstances of accounting errors. The Accounting Review 66 (3): 643-655. 
DeAngelo, L., 1981. Auditor size and auditor quality. Journal of Accounting and Economics (3): 183-99.

Evans, J., Patton, J., 1983. An Economic Analysis of Participation in the Municipal Finance Officers Association Certificate of Conformance Program. Journal of Accounting and Economics 5: 151-175.

Evans, J., Patton, J., 1987. Signaling and monitoring in public-sector accounting. Journal of Accounting Research 25 (Supplement): 130-158.

Faleye, O., 2007. Classified boards, firm value, and management entrenchment. Journal of Financial Economics 83 (2): 501-529.

Fama, E., Jensen, M., 1983. Agency problems and residual claims. Journal of Law and Economics 26(2): 327-349.

Gordon, T., 2009. Bargaining in the shadow of the ballot box: causes and consequences of local voter initiatives. Public Choice 141 (1-2): 31-49.

Gore, A. 2009. Why do Cities Hoard Cash? Determinants and Implications of Municipal Cash Holdings. The Accounting Review 84 (1): 183-207.

Government Accountability Office (GAO), 2007. Government Auditing Standards, GAO-07-731G, July.

Government Accountability Office (GAO), 2010. State and Local Governments. Fiscal Pressures Could Have Implications for Future Delivery of Intergovernmental Programs. GAO-10-899, July.

Government Finance Officers Association (GFOA). 2006. Recommended Practice on Audit Committees Compared with Sarbanes Oxley Requirements/SEC Regulation 338220/Blue Ribbon Committee Recommendations, mimeo (January 12).

Graham, J., Li, S., Qiu, J., 2008. Corporate misreporting and bank loan contracting. Journal of Financial Economics 89 (1): 44-61.

Greenblatt, A., 2005. Paradise Insolvent. Governing (Novebmer) 41.

Hammersley, J., 2006. Pattern identification and industry-specialist auditors. The Accounting Review 81 (2): 309-336.

Heckman, J., 1979. Sample selection bias as a specification error. Econometrica 47 (1): 153-161. 
Hennes, K., Leone, A., Miller, B., 2008. The importance of distinguishing errors from irregularities in restatement research: The case of restatements and $\mathrm{CEO} / \mathrm{CFO}$ turnover. The Accounting Review 83(6): 1487-1519.

Hribar, P., Jenkins, J., 2004. The effect of accounting restatements on earnings revisions and the estimated cost of capital. Review of Accounting Studies 9 (2-3): 337-56.

Jensen, M., Meckling, W., 1976. Theory of the firm: managerial behavior, agency costs and ownership structure. Journal of Financial Economics 3 (4): 305-360.

Kolenikov, S., Angeles, G. 2004. The use of discrete data in PCA: theory, simulations, and applications to socioeconomic indices. Unpublished working paper, University of North Carolina - Chapel Hill.

Laver, M., 1981. The Politics of Private Desires. Penguin Books, Harmondsworth; Penguin Viking, New York.

Lazer, R., Livnat, J., Tan, C., 2004. Restatements and accruals after auditor changes. Unpublished working paper. New York University.

Matsusaka, J., 2005. The eclipse of legislatures: Direct democracy in the $21^{\text {st }}$ century. Public Choice 124 (1-2): 157-177.

McMullen, D., 1996. Audit committee performance: An investigation of the consequences associated with audit committees. Auditing: A Journal of Practice \& Theory 15 (1): 87-103.

Moody's, 2004a. Moody's Downgrades City of San Diego GO Bonds to Aa3 from Aa1. Moody's Investors Service, 10 August.

Moody's, 2004b. Revised: Moody's Downgrades City of San Diego GO Bonds to A1 from Aa3. Moody's Investors Service, 24 September.

Palmrose, Z., Richardson, V., Scholz, S., 2004. Determinants of market reactions to restatement announcements. Journal of Accounting and Economics 37 (1): 59-89.

Srinivasan, S., 2005. Consequences of financial reporting failure for outside directors: Evidence from accounting restatements and audit committee members. Journal of Accounting Research 43 (2): 291-334.

Walker, D., 2005. Fiscal year 2004 U.S. government financial statements - sustained improvement in federal financial management is crucial to addressing our nation's future fiscal challenges. Testimony before the committee on government reform, U.S. House of Representatives, February 9. 
Wild, J., 1996. The audit committee and earnings quality. Journal of Accounting, Auditing and Finance 11 (2): 247-276.

Zimmerman, J., 1977. The municipal accounting maze: an analysis of political incentives. Journal of Accounting Research 15: 107-144. 
TABLE 1

Summary of sampling procedures

Panel A: Data collection

\begin{tabular}{lrr}
\hline & \# municipalities & \# financial reports \\
\hline Total cities and towns in ICMA governance database & 4,244 & 16,976 \\
Less governments with population $<50,000$ & $-3,879$ & $-15,516$ \\
Total cities and townships with populations $>$ 50,000 & 365 & 1,460 \\
Less those with financial reports unavailable & $\underline{-112}$ & $\underline{-719}$ \\
Sample with financial reports & $\underline{253}$ & $\underline{741}$ \\
$\quad$ Financial reports collected online & $\underline{227}$ \\
$\quad$ Financial reports collected from municipalities & $\underline{\underline{253}}$ & $\underline{\underline{471}}$ \\
Total municipalities & $\underline{\underline{207}}$ \\
Data missing for explanatory variables & $\underline{110}$ & \\
Sample with complete data (primary sample) & $\underline{97}$ & \\
Municipalities with restatements during 2001 to 2004 & a & \\
Municipalities with no restatements &
\end{tabular}

a Restatements are identified by searching financial reports for the keywords "restate," "restated," "restatement," and "prior period adjustment." 
TABLE 2

Descriptive statistics for specifications of restatement probabilities

\begin{tabular}{|c|c|c|c|c|c|c|c|}
\hline & \multicolumn{2}{|c|}{$\begin{array}{c}\text { Full sample } \\
(n=207)\end{array}$} & \multicolumn{2}{|c|}{$\begin{array}{l}\text { Restatements } \\
\quad(n=110)\end{array}$} & \multicolumn{2}{|c|}{$\begin{array}{l}\text { No restatements } \\
\qquad(n=97)\end{array}$} & \multirow{2}{*}{$\begin{array}{c}\text { Difference } \\
\text { (7) }\end{array}$} \\
\hline Variable & $\begin{array}{c}\text { Mean } \\
\text { (median) } \\
(1)\end{array}$ & $\begin{array}{c}\text { Standard } \\
\text { deviation } \\
\text { (2) }\end{array}$ & $\begin{array}{c}\text { Mean } \\
\text { (median) } \\
(3)\end{array}$ & $\begin{array}{c}\text { Standard } \\
\text { deviation } \\
\text { (4) }\end{array}$ & $\begin{array}{c}\text { Mean } \\
\text { (median) } \\
(5)\end{array}$ & $\begin{array}{c}\text { Standard } \\
\text { deviation } \\
(6)\end{array}$ & \\
\hline \multicolumn{8}{|c|}{ Audit oversight measures } \\
\hline Big 4 auditor & $\begin{array}{c}0.23 \\
(0.00)\end{array}$ & 0.42 & $\begin{array}{c}0.15 \\
(0.00)\end{array}$ & 0.36 & $\begin{array}{c}0.31 \\
(0.00)\end{array}$ & 0.46 & $7.03 * * *$ \\
\hline Municipal specialist & $\begin{array}{c}0.39 \\
(0.00)\end{array}$ & 0.49 & $\begin{array}{c}0.40 \\
(0.00)\end{array}$ & 0.49 & $\begin{array}{c}0.37 \\
(0.00)\end{array}$ & 0.49 & 0.18 \\
\hline State auditor & $\begin{array}{c}0.06 \\
(0.00)\end{array}$ & 0.24 & $\begin{array}{c}0.10 \\
(0.00)\end{array}$ & 0.30 & $\begin{array}{c}0.02 \\
(0.00)\end{array}$ & 0.14 & $5.53 * *$ \\
\hline Auditor switch & $\begin{array}{c}0.32 \\
(0.00)\end{array}$ & 0.47 & $\begin{array}{c}0.39 \\
(0.00)\end{array}$ & 0.49 & $\begin{array}{c}0.25 \\
(0.00)\end{array}$ & 0.43 & $4.85 * *$ \\
\hline Audit committee & $\begin{array}{c}0.26 \\
(0.00)\end{array}$ & 0.44 & $\begin{array}{c}0.26 \\
(0.00)\end{array}$ & 0.44 & $\begin{array}{c}0.26 \\
(0.00)\end{array}$ & 0.44 & 0.01 \\
\hline $\begin{array}{l}\text { Audit oversight } \\
\text { index }\end{array}$ & $\begin{array}{c}1.55 \\
(1.00)\end{array}$ & 0.75 & $\begin{array}{c}1.42 \\
(1.00)\end{array}$ & 0.71 & $\begin{array}{l}1.69 \\
(2.00)\end{array}$ & 0.77 & $6.67 * * *$ \\
\hline \multicolumn{8}{|c|}{ Voter oversight measures } \\
\hline Staggered & $\begin{array}{c}0.79 \\
(1.00)\end{array}$ & 0.41 & $\begin{array}{c}0.82 \\
(1.00)\end{array}$ & 0.39 & $\begin{array}{c}0.75 \\
(1.00)\end{array}$ & 0.43 & 1.33 \\
\hline $\begin{array}{l}\text { Political } \\
\text { competition }\end{array}$ & $\begin{array}{c}0.33 \\
(0.00)\end{array}$ & 0.47 & $\begin{array}{c}0.33 \\
(0.00)\end{array}$ & 0.47 & $\begin{array}{c}0.34 \\
(0.00)\end{array}$ & 0.48 & 0.25 \\
\hline Both provisions & $\begin{array}{c}0.32 \\
(1.00)\end{array}$ & 0.47 & $\begin{array}{c}0.30 \\
(0.00)\end{array}$ & 0.46 & $\begin{array}{c}0.34 \\
(1.00)\end{array}$ & 0.48 & 0.38 \\
\hline No provisions & $\begin{array}{c}0.33 \\
(0.00)\end{array}$ & 0.47 & $\begin{array}{c}0.31 \\
(0.00)\end{array}$ & 0.46 & $\begin{array}{c}0.35 \\
(0.00)\end{array}$ & 0.48 & 0.40 \\
\hline Recall attempt & $\begin{array}{c}0.12 \\
(0.00)\end{array}$ & 0.33 & $\begin{array}{c}0.11 \\
(0.00)\end{array}$ & 0.31 & $\begin{array}{c}0.13 \\
(0.00)\end{array}$ & 0.34 & 0.30 \\
\hline $\begin{array}{l}\text { Voter oversight } \\
\text { index } \\
\text { Control variables }\end{array}$ & $\begin{array}{c}0.99 \\
(1.00)\end{array}$ & 0.83 & $\begin{array}{c}0.92 \\
(1.00)\end{array}$ & 0.84 & $\begin{array}{l}1.06 \\
(1.00)\end{array}$ & 0.81 & 1.55 \\
\hline GAAP & $\begin{array}{c}0.23 \\
(0.00)\end{array}$ & 0.42 & $\begin{array}{c}0.16 \\
(0.00)\end{array}$ & 0.37 & $\begin{array}{c}0.29 \\
(0.00)\end{array}$ & 0.46 & $5.38 * *$ \\
\hline Unregulated & $\begin{array}{c}0.16 \\
(0.00)\end{array}$ & 0.37 & $\begin{array}{c}0.16 \\
(0.00)\end{array}$ & 0.37 & $\begin{array}{c}0.15 \\
(0.00)\end{array}$ & 0.36 & 0.03 \\
\hline Council-manager & $\begin{array}{c}0.75 \\
(1.00)\end{array}$ & 0.43 & $\begin{array}{c}0.71 \\
(1.00)\end{array}$ & 0.46 & $\begin{array}{c}0.79 \\
(1.00)\end{array}$ & 0.41 & 1.97 \\
\hline Size & $\begin{array}{l}181,495 \\
(102,165)\end{array}$ & 324,722 & $\begin{array}{c}181,496 \\
(102,165)\end{array}$ & 324,772 & $\begin{array}{c}199,565 \\
(101,615)\end{array}$ & 414,119 & 0.75 \\
\hline Debt & $\begin{array}{l}1.96 \\
(1.39)\end{array}$ & 2.52 & $\begin{array}{c}2.08 \\
(1.43)\end{array}$ & 3.12 & $\begin{array}{c}1.83 \\
(1.31)\end{array}$ & 1.60 & 0.72 \\
\hline Deficit & $\begin{array}{c}0.01 \\
(0.00)\end{array}$ & 0.10 & $\begin{array}{c}0.01 \\
(0.00)\end{array}$ & 0.10 & $\begin{array}{c}0.01 \\
(0.00)\end{array}$ & 0.10 & 2.02 \\
\hline
\end{tabular}

$* *, * * *$ indicate two-tailed significance at $\mathrm{p}<0.05$, and 0.01 . 


\section{Notes to Table 2}

Independent variables are computed as follows. Big 4 auditor is an indicator variable equal to one if the municipality's financial statements are audited by one of the largest four audit firms; Municipal specialist is an indicator variable equal to one if the municipality's financial statements are audited by a government audit specialist that is not a member of the Big Four; State auditor is an indicator set to one if the municipality's financial statements are audited by a state government auditor; Auditor switch is an indicator set to one if the municipality switched auditors during 2001-2004; Audit committee is an indicator equal to one if the municipality has an audit committee; the combined Audit oversight measure is computed as (Big 4 auditor + Municipal specialist + Audit committee $+[1$ - Auditor switch $]$ ); Staggered is an indicator variable equal to one if council elections are staggered; Political competition is an indicator variable equal to one when incumbents standing for election are not re-elected to the city council during the 2001-2004 period; Both provisions is an indicator equal to one if the municipality has initiative and referendum provisions, else zero; No provisions is an indicator equal to one if the municipality has neither initiative nor referendum provisions, else zero; Recall attempt is an indicator set to one if citizens attempted to recall either the mayor or a council member in the preceding five years; the combined Voter oversight measure is computed as (Political competition + [1 -

Staggered] + Both provisions + Recall attempt); GAAP is an indicator equal to one for states that mandate all municipalities follow GAAP disclosure requirements, else zero; Unregulated is an indicator equal to one for states that do not regulate municipal disclosure requirements, else zero; Council-manager is an indicator equal to one for municipalities with the council-manager form of government; Size is mean log of population over the sample period; Debt is the average total debt outstanding divided by total population over the sample period; and Deficit is an indicator equal to one if total revenues less expenses is less than zero in any of the sample years. 
TABLE 3

Determinants of municipal restatements $(n=207)$

\begin{tabular}{|c|c|c|c|c|c|c|c|}
\hline & 1 & 2 & 3 & 4 & 5 & 6 & 7 \\
\hline & $\begin{array}{c}\text { Full } \\
\text { specification }\end{array}$ & $\begin{array}{c}\text { Audit } \\
\text { oversight } \\
\text { measures } \\
\text { only }\end{array}$ & $\begin{array}{c}\text { Voter } \\
\text { oversight } \\
\text { measures } \\
\text { only }\end{array}$ & $\begin{array}{c}\text { Both audit } \\
\text { and voter } \\
\text { oversight } \\
\text { indices }\end{array}$ & $\begin{array}{l}\text { Audit } \\
\text { oversight } \\
\text { index }\end{array}$ & $\begin{array}{l}\text { Voter } \\
\text { oversight } \\
\text { index }\end{array}$ & $\begin{array}{c}\text { Controls } \\
\text { only }\end{array}$ \\
\hline Audit oversight: & & & & $\begin{array}{l}-0.52 \\
(-2.81)^{* * *}\end{array}$ & $\begin{array}{l}-0.63 \\
(-3.89)^{* * *}\end{array}$ & & \\
\hline Big 4 auditor & $\begin{array}{l}-1.02 \\
(-2.33)^{* *}\end{array}$ & $\begin{array}{l}-1.08 \\
(-2.28)^{* *}\end{array}$ & & & & & \\
\hline $\begin{array}{l}\text { Municipal } \\
\text { specialist }\end{array}$ & $\begin{array}{l}-0.49 \\
(-1.66)^{*}\end{array}$ & $\begin{array}{l}-0.86 \\
(-3.42) * * *\end{array}$ & & & & & \\
\hline State auditor & $\begin{array}{c}1.10 \\
(2.44)^{* * * *}\end{array}$ & $\begin{array}{l}1.02 \\
(2.47) * * *\end{array}$ & & & & & \\
\hline Auditor switch & $\begin{array}{c}0.77 \\
(2.96)^{* * *}\end{array}$ & $\begin{array}{l}0.70 \\
(2.98) * * *\end{array}$ & & & & & \\
\hline Audit committee & $\begin{array}{l}-0.09 \\
(-0.33)\end{array}$ & $\begin{array}{c}-0.13 \\
(-0.53)\end{array}$ & & & & & \\
\hline Voter oversight: & & & & $\begin{array}{l}-0.37 \\
(-3.95)^{* * *}\end{array}$ & & $\begin{array}{l}-0.51 \\
(-4.69)^{* * *}\end{array}$ & \\
\hline Staggered & $\begin{array}{l}0.65 \\
(2.32)^{* *}\end{array}$ & & $\begin{array}{l}0.62 \\
(2.15)^{* *}\end{array}$ & & & & \\
\hline $\begin{array}{l}\text { Political } \\
\text { competition }\end{array}$ & $\begin{array}{c}-0.27 \\
(-0.25)\end{array}$ & & $\begin{array}{l}-1.32 \\
(-1.31)\end{array}$ & & & & \\
\hline Both provisions & $\begin{array}{l}-0.57 \\
(-2.26)^{* *}\end{array}$ & & $\begin{array}{l}-0.73 \\
(-2.90) * * *\end{array}$ & & & & \\
\hline No provisions & $\begin{array}{l}-0.18 \\
(-0.61)\end{array}$ & & $\begin{array}{l}-0.38 \\
(-1.28)\end{array}$ & & & & \\
\hline Recall attempt & $\begin{array}{c}-0.69 \\
(-1.89)^{*}\end{array}$ & & $\begin{array}{l}-0.79 \\
(-2.09)^{* *}\end{array}$ & & & & \\
\hline $\begin{array}{l}\text { Control } \\
\text { variables: }\end{array}$ & & & & & & & \\
\hline GAAP & $\begin{array}{l}-0.59 \\
(-2.32)^{* *}\end{array}$ & $\begin{array}{l}-0.76 \\
(-3.15)^{* * *}\end{array}$ & $\begin{array}{l}-0.88 \\
(-3.27)^{* * *}\end{array}$ & $\begin{array}{l}-0.64 \\
(-2.67)^{* * *}\end{array}$ & $\begin{array}{l}-0.89 \\
(-2.62) * * *\end{array}$ & $\begin{array}{l}-0.79 \\
(-2.20)^{* *}\end{array}$ & $\begin{array}{l}-1.23 \\
(-5.14)^{* * *}\end{array}$ \\
\hline Unregulated & $\begin{array}{l}-0.01 \\
(-0.02)\end{array}$ & $\begin{array}{l}-0.10 \\
(-0.37)\end{array}$ & $\begin{array}{l}-0.37 \\
(-1.65)^{*}\end{array}$ & $\begin{array}{l}-0.22 \\
(-0.82)\end{array}$ & $\begin{array}{l}-0.17 \\
(-0.43)\end{array}$ & $\begin{array}{l}-0.45 \\
(-1.18)\end{array}$ & $\begin{array}{l}-0.52 \\
(-2.44)^{* * *}\end{array}$ \\
\hline Council-manager & $\begin{array}{l}-0.46 \\
(-1.46)\end{array}$ & $\begin{array}{l}-0.20 \\
(-0.62)\end{array}$ & $\begin{array}{l}-0.72 \\
(-2.15)^{* *}\end{array}$ & $\begin{array}{l}-0.58 \\
(-1.94)^{*}\end{array}$ & $\begin{array}{l}-0.37 \\
(-1.08)\end{array}$ & $\begin{array}{l}-0.72 \\
(-2.04)^{* *}\end{array}$ & $\begin{array}{l}-0.44 \\
(-1.34)\end{array}$ \\
\hline Size & $\begin{array}{c}0.12 \\
(0.46)\end{array}$ & $\begin{array}{l}-0.16 \\
(-0.63)\end{array}$ & $\begin{array}{l}-0.11 \\
(-0.61)\end{array}$ & $\begin{array}{c}0.03 \\
(0.17)\end{array}$ & $\begin{array}{l}-0.24 \\
(-1.20)\end{array}$ & $\begin{array}{l}-0.12 \\
(-0.58)\end{array}$ & $\begin{array}{l}-0.51 \\
(-3.24)^{* * *}\end{array}$ \\
\hline Debt & $\begin{array}{c}0.06 \\
(1.23)\end{array}$ & $\begin{array}{c}0.02 \\
(0.59)\end{array}$ & $\begin{array}{c}0.06 \\
(1.43)\end{array}$ & $\begin{array}{c}0.07 \\
(1.57)\end{array}$ & $\begin{array}{c}0.03 \\
(0.45)\end{array}$ & $\begin{array}{c}0.05 \\
(0.75)\end{array}$ & $\begin{array}{l}-0.00 \\
(-0.10)\end{array}$ \\
\hline Deficit & $\begin{array}{l}-0.45 \\
(-0.21)\end{array}$ & $\begin{array}{l}-1.04 \\
(-0.53)\end{array}$ & $\begin{array}{l}-0.14 \\
(-0.07)\end{array}$ & $\begin{array}{l}-0.07 \\
(-0.03)\end{array}$ & $\begin{array}{l}-0.70 \\
(-0.50)\end{array}$ & $\begin{array}{c}0.05 \\
(0.03)\end{array}$ & $\begin{array}{l}-0.78 \\
(-0.45)\end{array}$ \\
\hline Intercept & $\begin{array}{l}-0.93 \\
(-0.31)\end{array}$ & $\begin{array}{c}2.66 \\
(0.90)\end{array}$ & $\begin{array}{c}2.18 \\
(1.01)\end{array}$ & $\begin{array}{c}1.34 \\
(0.61)\end{array}$ & $\begin{array}{c}4.33 \\
(1.90)^{*}\end{array}$ & $\begin{array}{c}2.71 \\
(1.14)\end{array}$ & $\begin{array}{l}6.93 \\
(3.71)^{* * *}\end{array}$ \\
\hline Pseudo $\mathrm{R}^{2}$ & 0.14 & 0.12 & 0.06 & 0.09 & 0.07 & 0.05 & 0.05 \\
\hline
\end{tabular}

$*, * *, * * *$ indicate two-tailed significance at $\mathrm{p}<0.10,0.05$, and 0.01 . 


\section{Notes to Table 3}

Entries are logit estimates for specifications of restatement probability. The dependent variable is an indicator variable equal to 1 for municipalities that disclosed at least one accounting restatement between the years 2001 and 2004. Z-statistics, computed using robust standard errors clustered on state, are shown parenthetically. For brevity, estimates are not reported for dummy variables that delineate observations by calendar year.

Independent variables are computed as follows. The combined Audit oversight measure is computed as (Big 4 auditor + Municipal specialist + Audit committee + [1 - Auditor switch]); Big 4 auditor is an indicator variable equal to one if the municipality's financial statements are audited by one of the largest four audit firms; Municipal specialist is an indicator variable equal to one if the municipality's financial statements are audited by a government audit specialist that is not a member of the Big Four; State auditor is an indicator set to one if the municipality's financial statements are audited by a state government auditor; Auditor switch is an indicator set to one if the municipality switched auditors during 2001-2004; Audit committee is an indicator equal to one if the municipality has an audit committee; the combined Voter oversight measure is computed as (Political competition $+[1$-Staggered $]+$ Both provisions + Recall attempt); Staggered is an indicator variable equal to one if council elections are staggered; Political competition is an indicator variable equal to one when incumbents standing for election are not re-elected to the city council during the 2001-2004 period; Both provisions is an indicator equal to one if the municipality has initiative and referendum provisions, else zero; No provisions is an indicator equal to one if the municipality has neither initiative nor referendum provisions, else zero; Recall attempt is an indicator set to one if citizens attempted to recall either the mayor or a council member in the preceding five years; GAAP is an indicator equal to one for states that mandate all municipalities follow GAAP disclosure requirements, else zero; Unregulated is an indicator equal to one for states that do not regulate municipal disclosure requirements, else zero; Council-manager is an indicator equal to one for municipalities with the council-manager form of government; Size is mean log of population over the sample period; Debt is the average total debt outstanding divided by total population over the sample period; and Deficit is an indicator equal to one if total revenues less expenses is less than zero in any of the sample years. 


\section{TABLE 4}

\section{Descriptive statistics for specifications of municipal debt costs}

\begin{tabular}{|c|c|c|c|}
\hline & Mean & Median & Standard deviation \\
\hline \multicolumn{4}{|c|}{ Characteristics of 373 debt issues } \\
\hline TIC & 4.06 & 4.11 & 0.83 \\
\hline Bond Buyer index & 4.87 & 4.89 & 0.42 \\
\hline Competitively bid & 0.95 & 1.00 & 0.21 \\
\hline $\mathrm{GO}$ issue & 0.76 & 1.00 & 0.43 \\
\hline Bank qualified & 0.10 & 0.00 & 0.30 \\
\hline Call provision & 0.82 & 1.00 & 0.39 \\
\hline GFOA certificate & 0.88 & 1.00 & 0.32 \\
\hline Maturity & 16.93 & 18.26 & 6.55 \\
\hline Issue amount (000s) & $23,785.64$ & $9,750.00$ & $39,752.45$ \\
\hline Size $(000 s)$ & 231.36 & 124.67 & 229.80 \\
\hline Population growth & 0.24 & 0.09 & 0.41 \\
\hline Bond rating & 2.65 & 1.00 & 3.47 \\
\hline \multicolumn{4}{|c|}{ Governance characteristics of 57 municipalities that issue debt } \\
\hline \multicolumn{4}{|c|}{ Audit oversight measures $(n=57)$ : } \\
\hline Big 4 auditor & 0.21 & 0.00 & 0.41 \\
\hline Municipal specialist & 0.36 & 0.00 & 0.48 \\
\hline State auditor & 0.27 & 0.00 & 0.45 \\
\hline Audit committee & 0.22 & 0.00 & 0.41 \\
\hline Auditor switch & 0.30 & 0.00 & 0.46 \\
\hline Audit oversight index & 1.48 & 1.00 & 0.72 \\
\hline \multicolumn{4}{|c|}{ Voter oversight measures $(n=57)$ : } \\
\hline Staggered & 0.77 & 1.00 & 0.42 \\
\hline Political competition & 0.33 & 0.00 & 0.47 \\
\hline Both provisions & 0.32 & 0.00 & 0.47 \\
\hline No provisions & 0.24 & 0.00 & 0.43 \\
\hline Recall attempt & 0.14 & 0.00 & 0.34 \\
\hline Voter oversight index & 1.01 & 1.00 & 0.92 \\
\hline
\end{tabular}

Variables descriptions are as follows. True interest cost (TIC) is computed as the discount rate that equates the present value of the bond principal and interest payments with proceeds; Bond Buyer index of market yields for municipal general obligation or revenue bonds; Competitively bid is a dummy variable set to 1 for sales through a competitive bidding process; GO issue is a dummy variable set to 1 for general obligation issues, and 0 for revenue issues; Bank qualified is a dummy variable set to 1 if the issue qualifies for preferential tax treatment by bank lenders; Call provision is a dummy variable set to 1 if any part of the issue is callable; GFOA certificate is a dummy variable equal to 1 if the municipality is awarded the GFOA certificate; Maturity is the number of years until the bond's maturity; Issue amount is the face value of the issue; Size is the log of population; Population growth is the population change over the preceding five years; and Bond rating indicates Moody's ratings, where Aaa $=1$, and the numerical rating increases by 1 as 
the bond rating declines. Big 4 auditor is an indicator variable equal to one if the municipality's financial statements are audited by one of the largest four audit firms; Municipal specialist is an indicator variable equal to one if the municipality's financial statements are audited by a government audit specialist that is not a member of the Big Four; State auditor is an indicator set to one if the municipality's financial statements are audited by a state government auditor; Audit committee is an indicator equal to one if the municipality has an audit committee; Auditor switch is an indicator set to one if the municipality switched auditors during 2001-2004; the Audit oversight index is computed as (Big 4 auditor + Municipal specialist + Audit committee + [1Auditor switch] ); Staggered is an indicator variable equal to one if council elections are staggered; Political competition is an indicator variable equal to one when incumbents standing for election are not re-elected to the city council during the 2001-2004 period; Both provisions is an indicator equal to one if the municipality has initiative and referendum provisions, else zero; No provisions is an indicator equal to one if the municipality has neither initiative nor referendum provisions, else zero; Recall attempt is an indicator set to one if citizens attempt to recall either the mayor or a council member in the preceding five years; and the Voter oversight index is computed as (Political competition + [1-Staggered] + Both provisions + Recall attempt). 
TABLE 5

\section{Specifications of true interest cost (TIC) for debt issues three years before versus after restatement disclosure}

\begin{tabular}{|c|c|c|c|c|c|}
\hline $\begin{array}{l}\text { Dependent } \\
\text { variable }\end{array}$ & $\begin{array}{l}\text { TIC less Bond } \\
\text { Buyer Index }\end{array}$ & \multicolumn{4}{|c|}{ True interest cost (TIC) } \\
\hline \multirow[t]{2}{*}{ Sample } & $\begin{array}{l}\text { All debt issues } \\
\quad(\mathrm{n}=373)\end{array}$ & $\begin{array}{l}\text { All debt issues } \\
\quad(\mathrm{n}=373)\end{array}$ & $\begin{array}{c}\text { Audit oversight } \\
\text { only } \\
(\mathrm{n}=373)\end{array}$ & $\begin{array}{c}\text { Voter oversight } \\
\text { only } \\
(n=373)\end{array}$ & $\begin{array}{c}\text { Both audit and } \\
\text { voter oversight } \\
(\mathrm{n}=373)\end{array}$ \\
\hline & 1 & 2 & 3 & 4 & 5 \\
\hline Post-restatement & $\begin{array}{l}0.35 \\
(3.97)^{* * *}\end{array}$ & $\begin{array}{l}0.35 \\
(5.04)^{* * *}\end{array}$ & $\begin{array}{l}0.63 \\
(5.28) * * *\end{array}$ & $\begin{array}{l}0.49 \\
(6.33)^{* * *}\end{array}$ & $\begin{array}{l}0.93 \\
(6.79)^{* * *}\end{array}$ \\
\hline Audit oversight index & & & $\begin{array}{l}0.19 \\
(3.90)^{* * *}\end{array}$ & & $\begin{array}{l}0.22 \\
(3.88)^{* * *}\end{array}$ \\
\hline Audit oversight index & & & -0.20 & & -0.27 \\
\hline * post-restatement & & & $(-2.72)^{* * *}$ & & $(-3.84) * * *$ \\
\hline Voter oversight index & & & & $\begin{array}{c}0.06 \\
(1.20)\end{array}$ & $\begin{array}{l}0.11 \\
(2.58)^{*}\end{array}$ \\
\hline Voter oversight index & & & & -0.15 & -0.20 \\
\hline$*$ post-restatement & & & & $(-1.94) * *$ & $(-3.67)^{* * *}$ \\
\hline Bond Buyer index & & $\begin{array}{c}1.11 \\
(12.00)^{* * *}\end{array}$ & $\begin{array}{c}1.08 \\
(11.94)^{* * *}\end{array}$ & $\begin{array}{c}1.10 \\
(12.08)^{* * *}\end{array}$ & $\begin{array}{c}1.05 \\
(12.33)^{* * *}\end{array}$ \\
\hline Competitively bid & & $\begin{array}{l}-0.08 \\
(-0.76)\end{array}$ & $\begin{array}{l}-0.12 \\
(-1.11)\end{array}$ & $\begin{array}{l}-0.05 \\
(-0.48)\end{array}$ & $\begin{array}{c}-0.06 \\
(-0.58)\end{array}$ \\
\hline GO issue & & $\begin{array}{l}0.26 \\
(3.83)^{* * *}\end{array}$ & $\begin{array}{l}0.23 \\
(3.74) * * *\end{array}$ & $\begin{array}{l}0.26 \\
(3.62) * * *\end{array}$ & $\begin{array}{l}0.21 \\
(3.55)^{* * *}\end{array}$ \\
\hline Bank qualified & & $\begin{array}{l}-0.20 \\
(-2.50)^{* * *}\end{array}$ & $\begin{array}{l}-0.22 \\
(-2.50)^{* * *}\end{array}$ & $\begin{array}{l}-0.21 \\
(-2.38)^{* *}\end{array}$ & $\begin{array}{l}-0.21 \\
(-2.23)^{* *}\end{array}$ \\
\hline Call provision & & $\begin{array}{l}0.67 \\
(9.61)^{* * *}\end{array}$ & $\begin{array}{l}0.69 \\
(9.33)^{* * *}\end{array}$ & $\begin{array}{l}0.68 \\
(9.07)^{* * *}\end{array}$ & $\begin{array}{l}0.73 \\
(8.84)^{* * *}\end{array}$ \\
\hline GFOA certificate & & $\begin{array}{l}0.27 \\
(3.61)^{* * *}\end{array}$ & $\begin{array}{l}0.29 \\
(4.60)^{* * *}\end{array}$ & $\begin{array}{l}0.20 \\
(2.42)^{* *}\end{array}$ & $\begin{array}{l}0.21 \\
(2.90)^{* * *}\end{array}$ \\
\hline Maturity $<5$ years & & $\begin{array}{l}-0.60 \\
(-1.81)^{*}\end{array}$ & $\begin{array}{l}-0.47 \\
(-1.52)\end{array}$ & $\begin{array}{l}-0.59 \\
(-1.71)^{*}\end{array}$ & $\begin{array}{l}-0.43 \\
(-1.35)\end{array}$ \\
\hline Maturity $>15$ years & & $\begin{array}{l}0.44 \\
(7.08)^{* * *}\end{array}$ & $\begin{array}{l}0.42 \\
(7.14)^{* * *}\end{array}$ & $\begin{array}{l}0.44 \\
(6.86)^{* * *}\end{array}$ & $\begin{array}{l}0.42 \\
(6.61)^{* * *}\end{array}$ \\
\hline Issue amount & & $\begin{array}{l}-0.04 \\
(-1.19)\end{array}$ & $\begin{array}{l}-0.02 \\
(-0.73)\end{array}$ & $\begin{array}{l}-0.04 \\
(-1.43)\end{array}$ & $\begin{array}{l}-0.03 \\
(-0.87)\end{array}$ \\
\hline Size & & $\begin{array}{l}-0.08 \\
(-2.22)^{* *}\end{array}$ & $\begin{array}{l}-0.09 \\
(-2.46)^{* *}\end{array}$ & $\begin{array}{l}-0.07 \\
(-2.00)^{* *}\end{array}$ & $\begin{array}{l}-0.09 \\
(-2.30)^{* *}\end{array}$ \\
\hline Population growth & & $\begin{array}{l}-0.24 \\
(-2.41)^{* * *}\end{array}$ & $\begin{array}{l}-0.27 \\
(-3.01)^{* * *}\end{array}$ & $\begin{array}{l}-0.26 \\
(-2.45)^{* * *}\end{array}$ & $\begin{array}{l}-0.28 \\
(-2.89) * * *\end{array}$ \\
\hline Bond rating & & $\begin{array}{l}0.04 \\
(2.68)^{* * *}\end{array}$ & $\begin{array}{l}0.04 \\
(2.60)^{* * *}\end{array}$ & $\begin{array}{l}0.04 \\
(2.76)^{* * *}\end{array}$ & $\begin{array}{l}0.04 \\
(2.65)^{* * *}\end{array}$ \\
\hline Intercept & $\begin{array}{l}-1.35 \\
(-6.81)^{* * *}\end{array}$ & $\begin{array}{l}-1.88 \\
(-2.75)^{* * *}\end{array}$ & $\begin{array}{l}-1.95 \\
(-3.09)^{* * *}\end{array}$ & $\begin{array}{l}-2.07 \\
(-2.79)^{* * *}\end{array}$ & $\begin{array}{l}-1.96 \\
(-2.65)^{* * *}\end{array}$ \\
\hline Adjusted $\mathrm{R}^{2}$ & 0.21 & 0.69 & 0.71 & 0.70 & 0.71 \\
\hline
\end{tabular}

$*, * *, * * *$ indicate two-tailed significance at $\mathrm{p}<0.10,0.05$, and 0.01 . 


\section{Notes to Table 5}

Entries are OLS estimates for specifications of true interest cost (TIC), computed as the discount rate that equates the present value of the bond principal and interest payments with proceeds. The dependent variable is TIC less the Bond Buyer index of market yields for municipal general obligation or revenue bonds in model 1, and TIC in models 2 through 5. T-statistics, computed using robust standard errors clustered on municipality, are shown parenthetically. For brevity, estimates are not displayed for intercept dummy variables that distinguish municipalities by state.

Independent variables are computed as follows. Post-restatement is an indicator variable set to 1 if the municipal bond is issued within 3 years after the date of restatement, and 0 if issued within 3 years prior to the date of restatement; the Audit oversight index is computed as (Big 4 auditor + Municipal specialist + Audit committee $+[1$ - Auditor switch $]$ ); the Voter oversight index is computed as (Political competition $+[1$-Staggered $]+$ Both provisions + Recall attempt); Bond Buyer index of market yields for municipal general obligation or revenue bonds; Competitively bid is a dummy variable set to 1 for sales through a competitive bidding process; GO issue is a dummy variable set to 1 for general obligation issues, and 0 for revenue issues; Bank qualified is a dummy variable set to 1 if the issue qualifies for preferential tax treatment by bank lenders; Call provision is a dummy variable set to 1 if any part of the issue is callable; GFOA certificate is a dummy variable equal to 1 if the municipality is awarded the GFOA certificate; Maturity $<5$ years and Maturity > 15 years are dummy variables set to 1 if the number of years until the bond's maturity is less than 5 years or greater than 15 years, respectively; Issue amount is the log of the face value of the issue; Size is the log of population; Population growth is the population change over the preceding five years; and Bond rating indicates Moody's ratings, where Aaa $=1$, and the numerical rating increases by 1 as the bond rating declines. 
TABLE 6

Specifications of true interest cost (TIC) for debt issues three years before versus after restatement disclosure Auditor and voter oversight measures considered separately

\begin{tabular}{|c|c|c|c|c|c|c|c|c|c|c|c|}
\hline \multirow{4}{*}{$\begin{array}{l}\text { Expected sign } \\
\text { on interaction } \\
\text { Interaction } \\
\text { with post- } \\
\text { restatement }\end{array}$} & \multirow[b]{2}{*}{$\begin{array}{c}\text { Post- } \\
\text { restatement }\end{array}$} & \multicolumn{5}{|c|}{ Audit oversight } & \multicolumn{5}{|c|}{ Voter oversight } \\
\hline & & $\begin{array}{l}\text { Big } 4 \\
\text { auditor }\end{array}$ & $\begin{array}{c}\text { Municipal } \\
\text { specialist }\end{array}$ & $\begin{array}{c}\text { State } \\
\text { auditor }\end{array}$ & $\begin{array}{l}\text { Auditor } \\
\text { switch }\end{array}$ & $\begin{array}{c}\text { Audit } \\
\text { committee }\end{array}$ & Staggered & $\begin{array}{c}\text { Political } \\
\text { competition }\end{array}$ & $\begin{array}{c}\text { Both } \\
\text { provisions }\end{array}$ & $\begin{array}{c}\text { No } \\
\text { provisions }\end{array}$ & $\begin{array}{l}\text { Recall } \\
\text { attempt }\end{array}$ \\
\hline & $\mathrm{n} / \mathrm{a}$ & $(-)$ & $(-)$ & $(?)$ & $(?)$ & $(-)$ & $(+)$ & $(-)$ & $(-)$ & $(+)$ & $(-)$ \\
\hline & $\mathrm{n} / \mathrm{a}$ & $\begin{array}{c}-0.16 \\
(-1.28)\end{array}$ & $\begin{array}{c}0.17 \\
(1.29)\end{array}$ & $\begin{array}{c}0.16 \\
(1.49)\end{array}$ & $\begin{array}{l}0.43 \\
(3.97)^{* * *}\end{array}$ & $\begin{array}{l}-0.39 \\
(-3.06)^{* * *}\end{array}$ & $\begin{array}{c}0.12 \\
(0.98)\end{array}$ & $\begin{array}{l}-0.39 \\
(-4.04)^{* * *}\end{array}$ & $\begin{array}{c}0.09 \\
(0.66)\end{array}$ & $\begin{array}{l}0.31 \\
(2.35)^{* *}\end{array}$ & $\begin{array}{l}-0.33 \\
(-3.48)^{* * *}\end{array}$ \\
\hline Main effect & $\begin{array}{l}0.71 \\
(4.60)^{* * *}\end{array}$ & $\begin{array}{c}0.13 \\
(1.30)\end{array}$ & $\begin{array}{c}0.15 \\
(1.77)^{*}\end{array}$ & $\begin{array}{l}-0.10 \\
(-0.68)\end{array}$ & $\begin{array}{l}-0.30 \\
(-3.53)^{* * *}\end{array}$ & $\begin{array}{c}0.29 \\
(2.78)^{* * *}\end{array}$ & $\begin{array}{l}-0.08 \\
(-0.65)\end{array}$ & $\begin{array}{l}0.41 \\
(6.29)^{* * *}\end{array}$ & $\begin{array}{l}-0.16 \\
(-1.98)^{* *}\end{array}$ & $\begin{array}{l}-0.17 \\
(-1.67)^{* *}\end{array}$ & $\begin{array}{l}0.25 \\
(3.14)^{* * *}\end{array}$ \\
\hline
\end{tabular}

$*, * *, * * *$ indicate two-tailed significance at $\mathrm{p}<0.10,0.05$, and 0.01 .

Independent variables are computed as follows. Post-restatement is an indicator variable set to 1 if the municipal bond is issued within 3 years after the date of restatement, and 0 if issued within 3 years prior to the date of restatement; Big 4 auditor is an indicator variable equal to one if the municipality's financial statements are audited by one of the largest four audit firms; Municipal specialist is an indicator variable equal to one if the municipality's financial statements are audited by a government audit specialist that is not a member of the Big Four; State auditor is an indicator set to one if the municipality's financial statements are audited by a state government auditor; Auditor switch is an indicator set to one if the municipality switched auditors during 2001-2004; Audit committee is an indicator equal to one if the municipality has an audit committee; Staggered is an indicator variable equal to one if council elections are staggered; Political competition is an indicator variable equal to one when incumbents running for election are not re-elected to the city council during the $2001-2004$ period; Both provisions is an indicator equal to one if the municipality has initiative and referendum provisions, else zero; No provisions is an indicator equal to one if the municipality has neither initiative nor referendum provisions, else zero; and Recall attempt is an indicator set to one if citizens attempted to recall either the mayor or a council member in the preceding five years. 